\title{
The Woman's Rights In The Japanese Society: Its Historical Perspective
}

\section{Tomoko Kimura Gaudioso *}

Summary: Introduction; The formation of Japanese people; Concept of Family in early Japan; The coming of the feudalism and its influence in the Ssystemof Marriage; the entry of Japan in the modernism; Conclusion.

\section{INTRODUCTION}

Japan, according to anthropologists, appeared around the century I BC as a nation characterized by a matriarchal society, differently of Europe that, according to Hernani Estrella (1975) started with a structure visibly patriarchal ${ }^{1}$. The old registration of China proves that fact by describing Japan as a nation governed by a woman called Himiko who, from her palace, dictated the duties to the people. That privileged position of the woman lasted long for at $\mathrm{XI} \mathrm{AD,} \mathrm{in} \mathrm{right} \mathrm{form} \mathrm{to} \mathrm{the} \mathrm{private} \mathrm{properties,} \mathrm{to} \mathrm{the}$ inheritance and in the use of own surnames, independent of the husbands.

As time goes by, in the period of continuous wars, men started to conquer their juridical space, taking the power in their hands. Deprived of rights that lasted a thousand years, the woman's condition gets to be precarious and little was recovered until the coming of the last Japanese Constitution, promulgated in 1947, when her juridical position was legally compared to the masculine sex. However, still persist many aspects regarding the woman's rights that should be considered not only of rights but as facts socially accepted.

\section{THE FORMATION OF THE JAPANESE PEOPLE}

Located in the east end of Asia, until today, little is known about the old inhabitants of the Japanese archipelago, (because in early times, Japan hadn't writing system) much less the appearance of Japan as a nation due to writing lack in that time. Anthropologists

\footnotetext{
1 According to the author, the western women suffered three different apprenticeships in the society when elapsing of the times: in the first moment as a thing that the man appropriates; in the second moment as companion, as member of the family and; last, as emancipated individual. ESTRELLA, Hernani. The woman's rights. Rio de Janeiro: José Confines ed. 1975, p. 12-3. 2 Jomon - prehistoric period of Japan that embraces to approximately $300 \mathrm{AC}$. That period is identified with this name because the inhabitants of the time used the strings (jo) to mark (mon) the surface of the ceramic.
} 
only discovered that the Japanese people passed of hunting and fishing activities to the agricultural activity around $300 \mathrm{BC}$. Analyzing the system of housing constructions of previous Japanese before that time, called Jomon Period ${ }^{2}$, it is noticed that there wasn't hierarchy in the community. The primitive houses were made of thatch roofs, armed directly in the dug ground, without use of columns, not demanding any more sophisticated knowledge in the construction technique. In that system, they lived in a community without division of classes neither government.

As agricultural technique is introduced in the continent, about the century II BC, the community of the archipelago suffers significant changes in its structure as the appearance of different social classes and society based on the government ${ }^{3}$. Such period of time, based on agriculture is known as Yayoi Period ${ }^{4}$.

The community that was limited to small groups of people, with the coming of the agriculture, starts increasing its members due to need of larger number of working hands. The accumulation of surpluses in the cultivation of rice and the appearance of different levels of economical power among people due to manpower, formed social classes favoring the political communities appearance in several areas of the archipelago. The oldest Chinese geography book called Guishi Wajinden, describes Japan of the century I BC by saying that "in the oversea there are people of Wa divided in more than a hundred countries" with its respective kings, proving that in this time there were already political systems, identifying more than a hundred different communities with defined hierarchy ${ }^{5}$.

It is believed that the imperial government's formation, with the unification of the countries happened among IV AD and VI AD with the dominance of the country of the central area of the main island, Honshu, over the others from east to west. That community's king (tribe) dominant would have been one ancestral of the emperor.

According to Ienaga (1967), the emperor recognized the local kings, however he was positioned as sovereign of these, governing them with his authority in federation form. The unification of the government power of Yamato, old Japan, can be proven through great invasions that that country accomplished oversea against the neighboring countries of the such like old countries of Kudara and Shiragi, of the peninsula of Korea, establishing government's headquarters in those places 6 .

As the social structure, the local kings denominated Goozoku, subordinates to the emperor, continued to subdue farmers and slaves. Like this, then, there were three social classes, the clans or dynasties of bosses of tribes, farmers and slaves, besides the figure of emperor.

\footnotetext{
3 IENAGA, Saburo. Nihon Bunkashi.Tokyo: Iwanami Shoten, 1967, p.16.

${ }^{4}$ Yayoi - period that embraces of approximately $200 \mathrm{AC}$ up to $300 \mathrm{DC}$. That denomination is due to the fact that the ceramic that mark that period was found at the place with that denomination, in the municipal district of Tokyo.

5 IENAGA, Saburo. Nihon Bunkashi.Tokyo: Iwanami Shoten, 1967, p.19

${ }^{6}$ Op. cit. p.22

7 Uji - noble lineage, dominant clans of early Japan. According to Nihongo daijiten, it is the denomination of consanguineous people's union that has the same ancestral. KANDAICHI, Haruhiko et alii, org.
} 
The farmers were subdivided in classes denominated of be, according to the handmade knowledge they possessed, this under influence of the Kudara system, today South Korea.

The goozoku possessed two types of names: $u j i^{7}$ that represented consanguineous relationship and $k a b a n e^{8}$ that represented aristocratic degree.

\section{CONCEPT OF FAMILY IN EARLY JAPAN}

Being spoken in clans or dynasties, it becomes indispensable to analyze family concept and system of marriage during such periods. According to lenaga, it is believed that in the primitive society of Japan the matriarchal system prevailed in spite of authority to govern it was in hands of the masculine sex'.

The marriage in the ancentry was rendered in such a way that the husband visited the house where inhabited the wife and the children regularly. That marriage system was called kayoikon ${ }^{10}$ but it lasted to the period in that the samurais started to dominate Japan, around the century XI. It is supposed that the goods such as pieces of furniture, and property, in this time, were transmitted from mother to daughter, being the people of feminine sex independent in relation to her husbands.

The marriage ceased with the end of the visits of the husband to his wife, putting term to it. However, in this time, as there wasn't control of visits, from both sexes, it is believed that those that maintained marital relationships were husbands and wives and there was not differentiation between wife and those with relationship out of the marriage.

In $645 \mathrm{AD}$ the central government, influenced by China, accomplished a great reform of general character called Reforms of Taika, promulgating a system of code of laws called Ritsuryoo. With that, it was established a nobility class divided in twelve levels identified with general denomination of kan ijyuunikai ${ }^{11}$, different from that of the $u j i-k a b a n e^{12}$. The people passed from individual's private position to the position of the "public" people and the no-people called zokumin. That regime recognizes three social classes of people to know: a) the imperial family; b) the subjects called free ryomin, subdivided in public employees and farmers and; c) subjects of inferior class called senmin, including slaves and servants of several categories.

Nihongo daijiten, Tokyo: Kodansha, 1989, p.168. also see YAMASHIRO, José. History of the samurais, São Paulo: IBRASA, 1993. p. 32, 273.

${ }^{8}$ Kabane - they were designated the kabane denomination to the family indicating the nobility degree or profession. Kabane was regularized in 683 DC by Emperor Temmu. Nowadays, that denomination indicates the last name although it is an archaic word for such. KANDAICHI, Haruhiko et alii, org. Nihongo daijiten, Tokyo: Kodansha, 1989, p.168; YAMASHIRO, José. History of the samurais, São Paulo: IBRASA, 1993, p.22-3; p.42-3 and p. 273.

9 IENAGA, Saburo. Nihon Bunkashi.Tóquio: Iwanami Shoten, 1967, p.40.

10 Kayoikon - it comes from the word kayou, that means to go and to return and kon that means marriage, in Japanese language.

11 Kan i jyuunikai - literally, the twelve steps of hierarchy.

${ }^{12}$ See notes 7 and 8 . In Japanese language, the word shi is also read uji, that means clan as it was already mentioned previously. Nowadays, that word indicates the surname of the family (kabane).

${ }^{13}$ The great farms were denominated shoen where produced farmings of rice. IENAGA, Saburo. Nihon bunkashi.Tóquio: Iwanami Shoten, 1967, p.78.

14 Myoden - literally, rice with name, in Japanese 
Between $727 \mathrm{AD}$ and the beginning of the century X, Japan accomplished intense cultural exchange with the countries of the continent, and the family system also suffered its effects. In relation to family, it was introduced the Chinese system that respected the patriarchy, at least, formally, establishing rules for the divorce and the children's obligation to their parents. That reform resulted in failure due to stronger local tradition. The system kayoikon still lasted long for several centuries. As result, was not rare to appear women lädies of great farms ${ }^{13}$.

\section{THE COMING OF THE FEUDALISM AND ITS INFLUENCE IN THE SYSTEM OF MARRIAGE}

The public lands, along the time, became distributed to the private with objective of increasing plowed areas. In the year of 743 , the government promulgated kondei, law of distribution of lands allowing farmers to own one area of lands as private property since they tamed it.

As result, beside the shoen, great lands of imperial property, of high nobility and of the clergy, increases the number of small proprietors of lands that, a lot of times preferred to pass the property to the other ones because they could not stay isolated. Those lands received owners' name and farmers. Those rice fields are denominated myô or myôden. ${ }^{14}$ The myôden proprietors become called myôshu, then the property right was hereditary. Those properties were sufficiently autonomous to characterize a feud.

Then, with the coming of the feudalism in Japan, in the century $\mathrm{XI}^{15}$, it appears the feudal lords, owners of lands. The social structure also suffers the change creating new entail type among the people. The relationship appears between gentleman and vassal, where the first to his committed your subjects the rights of to explore his lands for the cultivation or to give them new lands and to protect them and, in change, they demanded the fidelity so much from the same ones economical as it forces warlike, forcing them to participate in the fights to his side when necessary. The warriors that appeared in that age were called bushi or samurai. They served your gentlemen in change of rewards, in other words, those warriors' larger interest was the maintenance of their family and their descendants' prosperity.

The system of marriage kayoikon, with the coming of the feudalism, passed little by little to the system in that the wives started to live at the house of your husbands. The system of inheritance division for share, usual at first, was less and less practiced with the justification that the women didn't participate in the fights when wars came. Finally, it consolidated the succession system where the right to the inheritance concentrated one only masculine person, placing the woman in a position without any right.

15 The Revolt of Shokyu, in 1221 had great influence in the appearance of feudalism in Japan. It is interesting to consider that, in that period it also appears the feudalism in Europe in spite of the lack of any communication between Japan and the occident.

${ }^{16}$ YAMASHIRO, José. History of the samurais, São Paulo: IBRASA, 1993, P.51 and 56. According to the author, the fight for the power among the clans Genji and Taira lasted for more than two 
According to Yamashiro, the imperial court it self, to reduce the excessive number of princes, designated them new family names, moving them away from the court. That made possible to form new branches of the imperial family with different surnames, that culminated in the war north-south among two clans, Genji and Taira, that claimed legitimacy to be successor to the throne ${ }^{16}$.

Japan enters in the era of the dominance of the clan of Genji, of warlike origin, that established his govern in Kamakura, to the Southwest of current Tokyo. That period is called Kamakura Period and it lasted up to 1333.

In spite of being allowed to have a second wife as it happened in the aristocracy, in the family of the samurais, monogamy comes to be the rule and, in the case of sterility it fell back upon a consanguineous relative's adoption ${ }^{17}$ or to make a heir the son-in-law. According to the code of Kamakura, the head of the family had the unlimited power to choose his heir.

The samurai used to choose the son considered more capable to inherit his position, succeeding him after his retirement. However, having tradition of being the firstborn son to inherit the goods of the family, the code Jooei Shikimoku ${ }^{18}$ established that it stipulated the ignored firstborn son of the succession, to notice a fifth of the total of the goods of the family.

That succession system is due to the fact of Japanese to have the habit of worshipping the ancestors' spirit through domestic rituals, to perpetuate the surname and to supply the needs of the family ${ }^{19}$.

After the Kamakura Period, the country immerses in the period of bloody fights among local feudal lords. During more than two centuries, reunification of Japan made for great feudal gentlemen's appearance, beginning with Hideyoshi Toyotomi, followed by Nobunaga Oda and Ieyasu Tokunaga, and this last one acquired Seii Taishogun's position, the barbarians' of the east's greatest warlord combatant, concluding the unification of the power in his hands in 1600 that lasted up to 1868.

In 1543, 43 years after the discovery of Brazil, Japan knew the Christianity through the arrival of the Portuguese in the island of Tanegashima, to the south of the country ${ }^{20}$. However, in spite of having had cultural contact as feeding, the Christian religion or even the technologies of the occident such as construction of warlike and tactical

centuries that would culminate in victory of the clan of Genji, also known by Minamoto. The warriors of this time announced their family lineage when facing the enemy.

17 That adoption system to call yoshi, creation son.

${ }_{18}$ Jyooei shikimoku - also known by the name of Goseibai shikimoku, that code was elaborated for then regent Yasutoki Hojyo. Constituted of 51 articles, it was promulgated in 1232 by the government of Kamakura and for a long time it served as rules of conduct for the samurais. KANDAICHI, Haruhiko et alii, org. Nihongo daijiten, Tokyo: Kodansha, 1989, p.705.

19 In spite of the modernity, that cult habit to the ancestors persists until today and the only daughter not rarely has difficulties in finding a fiancé.

20 YAMASHIRO, José. History of the Japanese culture: São Paulo, IBRASA, 1986, p. 141 and next. 
weapons, the coming of the Portuguese couldn't influence the moral concept or the concept and the system of Japanese marriage.

On the contrary, the military government of Tokunaga, known as Xogunato, established its head in the city of Edo, current Tokyo. That period is known as Edo Period $^{21}$, was characterized with complete insulation of the country on strong allegation that any communication with foreign countries would threaten the national sovereignty. With the introduction of Confucianism already in the period of Iemitsu, the third generation of Tokunaga, he settles down a new division of social classes according to Chinese philosophy of the time.

According to Ienaga, in that period, all members of the society were divided according to their hierarchical position, inside of their respective classes that were the following ones: a) the warriors - shi; b) farmers - noomin; c) handmakers - koomin and; d) nomen - hinin or etta. Each one of them held its relationship between superior and subordinate, so much like the relationship between boss and employee as family relationships as husband on the wife, father in relation to their children, the superiority of the main house, the honke on the bunke, the ranification of that. In what cames to taking care of brothers, his hierarchical relationship was also observed.

The decadence of the woman's position in the society culminated with the arrival of the Confucianism. After the marriage, the wife entered as member of the husband's family, the $i$. Ienaga gets to compare that subordination of all members of the family to the patriarch, only legitimate heir of the goods, to the slavery model there was in Rome. The authority called ken-i, of the head of the family was absolute. The woman, once married, looses her entailment to the previous family and starts to belong to the family of the husband. However she was not entitled any in the new home mainly in relation to the goods. She was one more bride that it married with the "house", as a graft, than being married to the husband.

In that time, usually, the marriage was arranged by the parents with a middleman's intervention. The materialization of the marriage happened through the celebration of san san kudo, traditional ritual in that the engaged couple took a certain amount of sake, a fermented drink done of rice. The woman's infidelity was punished with death penalty unlike the husband that had free access to the women, besides of having second house with concubine, this also his slave ${ }^{22}$.

The book tituled "Yamato zokukun - the teaching of the daily of Yamato", written by Ekiken Kaibara $(1630-1714)^{23}$ enumerated several rules of the people's of that time conduct. According to the text, the human morals based on respecting the emperor. It's prohibited the critic of the people not authorized to the government's politics, the

${ }^{21}$ Edo Period - it lasted from 1603 to 1867. It is the period that the clan of Tokunaga, of warlike origin imposed his power on the country. On the matter, to consult YAMASHIRO, José. History of the Japanese culture: São Paulo, IBRASA, 1986, p. 149 and next.

22 On the matter, to see YAMASHIRO, José. History of the samurais, São Paulo: IBRASA, 1993, p. 178.

${ }^{23}$ Ekiken Kaibara - he lived from 1630 to 1714. Belonging to the government of the Kuroda han (the district govern of Kuroda), he was an eclectic man and follower to the Confucianism. Being great expert of the flora and the education, he traveled all through the whole Japan and had great contact with the researchers of his time. 
individuals should serve their parents and the firstborn brother. In relation to the women, the husband had absolute power.

The divorce, for instance, was granted to the husband when the woman infringed any of the following seven conditions: 1) to be jealous; 2) to be the bearer of any disease; 3 ) to be unable to generate children; 4) to talk too much; 5) to dress silk clothes; 6) to drink a lot of tea; and 7) to eat more than the necessary.

The rule of the Confucianism was demanding to the woman in such a way that she didn't delay those that opposed her to appear, just as Zanko Masuho that defended the reestablishment of the egalitarian relationship between men and women ${ }^{24}$.

Concerning the divorce right on the part of the wife, starting from the time that women started to reside at the house of the husband, it took place with the entry in the nuns' Buddhist monastery, called Enkiri-dera ${ }^{25}$, since it was not captured by the pursuers and it could reach the religious establishment. Like this, it was granted the "asylum" there to stay for three years against marriage when she no more wanted to give continuity. To it in the end of that period women reached liberty, ending-off any relationship with her husband and his family. Until the Edo Period, any Buddhist monastery of nuns was for that end. Later, the temple Tookeiji, of Kamakura and the temple Mantokuji of Kozukekoku Sedara ${ }^{26}$, were certain as only capable temple-monasteries they grant "asylum to wives" to women that wanted to put term to the marriage ${ }^{27}$.

Little by little, with the pacification of Japan and the merchants' economical ascension, the samurai status becomes a negotiable title. Like this, merchants that acquired rights before appear private of the samurai, obtaining the right of to use the last name and to carry sword, called myoji taitoo, by donation in money to the interested warrior. The merchants obtained the license of using the shi of the samurai. That license was granted in two ways, could be lifelong or hereditary ${ }^{28}$.

\footnotetext{
${ }^{24}$ In that time, free love was prohibited. The community's lovers' escape was punished according to the social position that the parts occupied. The criminal fugitives and farmers were the ones that suffered more serious penaltes even with death penalty. The lovers' couple's search was to the relatives' position or of the community's bosses. The tragedy works written by theater writer Monzaemon Tikamatsu $(1653$ - 1724) portrait woman's position well in the society on those time. On the subject, to see:

YAMASHIRO, José. History of the samurais, São Paulo: IBRASA,,1993, p.181. to also See SOGA, Tetsuo, org. Genshoku hyakka jiten.. Tokyo: Shogakukan, 1967, vol. 2, p.248.

${ }^{25}$ Enkiri-dera - from the word enkiri - breaking of relationships and the word tera, Buddhist temple. It is also known as kakekomi- dera, therefore the women, usually, enter running in its interior pursued by the husbands or other responsible of the community. If captured, she could suffer death penalty for the own member of the family.

${ }^{26}$ Kouzukekoku Sedara - current city of Ojima, of the province of Gumma.

${ }^{27}$ See SOGA, Tetsuo, org. Genshoku hyakka jiten.. Tokyo: Shogakukan, 1967, vol. 1, p.592.

${ }^{28}$ See KANDAICHI, Haruhiko et alii, org. Nihongo daijiten, Tokyo: Kodansha, 1989, p.1906.
} 


\section{THE ENTRY OF JAPAN IN THE MODERNISM}

In 1853 , four frigates of the United States, commanded by the commodore Matthew Perry arrived in Japan, forcing the opening of the ports to international trade. In 1867, emperor recovered the power and promulgated his politics of modernization of the country. The emperor established the politics of the kaikoku seisaku, in other words, the politics of the opening of the country to the foreigners removing Japan of the itself-confinement. After several political movements in favor and against, being the power of the weak samurais for the long peace period, finally, on January 3, 1868 it was proclaimed the restoration of full monarchy and emperor Meiji ${ }^{29}(1967$ - 1912) ascended to the throne, putting term to the system based on the government of militaries.

The opening of the ports created liberal movement that soon was controlled by the government. The first constitution was promulgated by emperor Meiji, in 1899, based on the such Germanic constitutions like the one of Bierne and Wertenberh, strengthening imperial power on the Japanese Diet.

Despite the opening of the ports, however, the western liberalism didn't reach the people in its great majority. The small farmers still depended on the community they belonged to and the own individuals continued with strong entail with the family. Like this, even same among the salary earners, the income only came from the husband, in such a way that women continued to limit their performance to the administration of the domestic expenses.

That feminine slavery influenced in the elaboration of the Japanese civil code, in the referring chapters to family law and successions, establishing an inequality between men and women as right concession to the inheritance to the firstborn son or the adopted son successor of the family $y^{30}$. The moral concept established by Confucianism was ingrained in the spirit of the Japanese people. According to the Institute of Statistical Research of the Ministry of the Culture ${ }^{31}$, the Japanese people mention in first place, the importance of serving their parents and in second, the retribution to the received favor. However, nowadays, that servitude to the family became substituted by more human feelings.

Concerning the registration of people, the system of family registration was adopted in Japan after the Meiji Restoration, with surname ${ }^{32}$ attribution to all citizens of the country,

${ }^{29}$ That change of government's system, of the militarism to the monarchism is known as Meiji Restoration (Meiji Ishin).

30 The succession seeks mainly the perpetuation of the being and not only to the inheritance of the patrimony. The adopted son with objective of happening in the family lineage in the previous Civil Code was denominated of yoshishi,different of the yoshi, the other adopted sons. It is interesting to observe that Japanese, in spite of giving importance to the consanguinity, sometimes adopted children without relationship bows. KANDAICHI, HARUHIKO ET ALII, ORG. Nihongo daijiten, Tokyo: ,Kodansha, 1989, p.2021.

${ }_{31}$ Source: Tokei Suri Kenkyujyo. In the last ten years, the servitude feeling to the parents grew from $63 \%$ to $73 \%$ and the retribution gets to occupy $50 \%$ of the Japanese youths' conscience.

${ }^{32}$ Atribued Surname or family name to All the japanese citizen. 
namely of the classes, unifying the surname of the wife to the surname of the husband ${ }^{33}$. After World War II, with the promulgation of the new Constitution and reformulation of the Japanese Civil Code, the "family concept" was excluded of its text.

The marriage, nowadays, is accomplished with simple declaration to the local authority through the delivery of the request and the article 750 of the Civil current Japanese Code establishes the compulsory nature of the choice of the last name common to the couple, of the husband or of the woman. Despite the code allows surname choice, when getting married, about $98 \%$ of the women starts to adopt the surname of the family of the husband ${ }^{34}$ showing that in the Japanese society still persists the concept of masculine superiority.

However, with the feminine ascension mainly in the economy, and for turning to assume important rows in society, women became recognized as individuals. The obligatory change of surname for the marriage on the part of the woman (since men would be also prejudiced in their professional activity if they changed it) it started to harm not rarely, the woman's activity. There are more women that choose not to get married to avoid the problem at professional activity. In order to solve the problem, in 1996, project of reform of the Civil Code was elaborated including the right of adoption of different surnames between among the couple ${ }^{35}$. However, this project was not approved.

\section{CONCLUSION}

The Japanese woman's juridical position went by different steps from the one of the occident. Firstly powerful, for the fact of holding in her hands the relative own rights to her goods and for the fact of could act in agreement with her own will, she lost her juridical and social space for the men owed the continuous internal wars in the country. After World War II, with the promulgation of the new Japanese constitution where it adopts the beginning of equality between both sexes, the Japanese woman passed becoming aware of her rights. Nowadays, there are not few women that act in the most several fields of professional activity, besides occupying important ministerial positions as leaders of the nation. However, there are still so many points that should be reconsidered in relation to women's rights, in the aspects of social rights as in the individual aspects, beginning with the right to have her own surname that is the individual's authentic recognition as an integral human being.

\footnotetext{
${ }^{33}$ According to Noriko Mizuno (2001), of the University of Tohoku, the individuals that you/they possessed surname until the end of the period Edo they were around $6 \%$ of the total population. In this period, women did adopt single' surname after the marriage. The Meiji Restoration established system of family registration forcing to the women to adopt the surname of the family that the woman belonged. Like this, when woman married, she get off her relationship of the parents' biological or even adoptive family. Like this, it was her allowed to come back once to her native house only a year, in the Deads' Festival, in August. To see MIZUNO, NORIKO. Minpou ga kazoku wo kiritsu shite isseiki. In: Manabi in the mori. Sendai: University of Tohoku, 2001. No16.

${ }^{34}$ Source: wuw.japanorama.com/koseki.html, 19.07.2002.

35 Source: TSUJIMURA, MIYOKO. Danjyo kyodo sankaku shakai no ho to seido. In: Manabi no mori. Sendai: University of Tohoku, 2001. №18
} 


\section{REFERENCES}

-ESTRELLA, Hernani. The woman's rights. Rio de Janeiro: José Confines ed. 1975. -IENAGA, Saburo. Nihon Bunkashi. Tóquio: Iwanami Shoten, 1967.

-HASHIMOTO, Hiroshi and HARA, Michio. Tikamatsu Monzaemon. Tokyo: Shinchosha, 1991.

-KANDAICHI, Haruhiko et alii, org. Nihongo daijiten. Tokyo: Kodansha, 1989.

-KASHIBARA, Seiichi. Yamataikoku Bussancho. Tokyo: Kawade Shobo, 1990.

-KONISHI, Shiro, org. Kurofune no jidai. Tokyo: Kawade Shobo, 1995.

-MAKINO, Kazuo and OGAWA, Kunio org. Heike monogatari. Tokyo: Shinchosha, 1995.

-MIZUNO, Noriko. Minpou ga kazoku wo kiritsu shite isseiki. In: Manabi no Mori. Sendai: University of Tohoku, 2001. №16.

-NAKANO, Koichi and MARUYA, Shuichi. Genji monogatari. Tokyo: Shinchosha, 1990.

-NISHIKI, Akie and SATO, Kazuhiko, org. Kamakura rekishi sampo. Tokyo: Kawade Shobo, 1995.

-SOGA, Tetsuo, org. Genshoku hyakka jiten. Tokyo: Shogakukan, 1967, vol. 2. -TOKEI SURI KENKYUJYO. Monbusho. Japan, 2000.

-TSUJIMURA, Miyoko. Danjyo kyodo sankaku shakai no hou to seido. In: Manabi no Mori. Sendai: University of Tohoku, 2001. №18

-YAMASHIRO, José. History of the samurais, São Paulo: IBRASA, 1993.

-www.japanorama.com/koseki.html, 19.07.2002.

* Coordinator of the Japanese Studies Department - NEJA and Professor of Japanese Language and Culture of the Federal University of Rio Grande do Sul-UFRGS. 